\title{
THERMAL CHARACTERISTICS OF THE PERMAFROST WITHIN AN ACTIVE ROCK GLACIER (MURTÈL/CORVATSCH, GRISONS, SWISS ALPS)
}

\author{
By Daniel Vonder Mühll and Wilfried Haeberli
}

(Versuchsanstalt für Wasserbau, Hydrologie und Glaziologie, ETH-Zentrum,

CH-8092 Zürich, Switzerland)

\begin{abstract}
Temperatures from a bore hole through an active rock glacier in the eastern Swiss Alps are presented and thermal conditions within the slowly creeping permafrost are analyzed. Present mean annual temperature in the uppermost part of the permafrost is $-3{ }^{\circ} \mathrm{C}$. Permafrost is $52 \mathrm{~m}$ thick and reaches heavily fissured bedrock. Thermal conductivity as determined in situ from seasonal temperature variations and measured in a cold laboratory using frozen samples is close to $2.5-3.0 \mathrm{~W} \mathrm{~m}^{-1}{ }^{\circ} \mathrm{C}^{-1}$. Vertical heat flow is anomalously high (around $150 \mathrm{~mW} \mathrm{~m}^{-2}$ ), probably due to heat advection from circulating ground water or air within the fissured bedrock zone. Beneath this zone, which could in fact represent a non-frozen intra-permafrost layer or "talik", relic permafrost from past centuries may possibly exist as indicated by a corresponding heat-flow inversion. Given the current temperature condition at the surface of the rock glacier and the fact that the twentieth century is among the warmest in post-glacial time, permafrost conditions may be assumed to have existed during the whole of the Holocene and, hence, during the entire time of rock-glacier formation.
\end{abstract}

\section{INTRODUCTION}

Thermal aspects are fundamental to understanding the formation, existence, preservation, and stability of ice in the ground. Rich information and correspondingly specialized literature is available concerning permafrost in polar lowlands (e.g. Gold and Lachenbruch, 1973; Lachenbruch and others, 1988), where increasing attention is now being paid to effects of ongoing secular warming trends (Osterkamp, 1984; Smith, 1988). In contrast, much less is known about the thermal conditions of mountain permafrost at lower latitudes, despite the fact that ice-rich permafrost at a high elevation is common. Creep of such permafrost on slopes is widespread and easily recognizable from the large number of striking, lava-stream-like rock glaciers (e.g. Wahrhaftig and Cox, 1959; Barsch, 1978; Haeberli, 1985; Giardino and Vitek, 1988).

Within the framework of a recently started core-drilling project, two bore holes were drilled into the permafrost of the active rock glacier Murtèl I (Fig. 1) near Piz Corvatsch, Engadin/Grisons, eastern Swiss Alps (Haeberli and others, 1988). The present paper describes the bore-hole temperatures measured during the first year of observation, discusses the thermal properties of the frozen material, and presents an analysis of the heat-flow conditions within the creeping rock-glacier permafrost. A complete description of the measurements has been given by Vonder Mühll (unpublished). Long-term monitoring of bore-hole temperatures is planned in order to improve the thermal analysis and to investigate possible effects of anticipated warming trends with respect to the stability of mountain permafrost on steep slopes.

\section{INVESTIGATED SITE}

The active rock glacier Murtèl $I$ is situated close to the lower boundary of the local permafrost distribution and, in fact, presently advances over permafrost-free terrain (Hölzle, unpublished). A number of measurements and soundings had previously been carried out at this easily accessible site (Barsch, 1973, 1977; Barsch and Hell, 1975; King and others, 1987). Surface altitude at the drill site is $2670 \mathrm{~m}$ a.s.1. and exposure is to the north-west. The activelayer thickness on the rock glacier is $2-4 \mathrm{~m}$ and perennially frozen, ice-rich sediments reach the slightly overdeepened bedrock. Surface movements are on the order of a few centimeters per year, reflecting compressive flow within the lower part of the rock-glacier lobe, where striking ogive-like transverse ridges exist.

In April, May, and June 1987, an experimental hole (bore hole I, $21 \mathrm{~m}$ ) and a deep hole (bore hole II, $62.5 \mathrm{~m})$ - separated by a horizontal distance of about $2 \mathrm{~m}$ - were drilled into the rock-glacier permafrost. To minimize thermal disturbance of the cores and the bore hole during drilling operations, a triple-tube coring system was used in combination with cold-air cooling (cf. Lange, 1973). The last piece of ice was found at $51 \mathrm{~m}$ depth, heavily fissured and highly permeable, non-frozen bedrock was reached at about $52 \mathrm{~m}$, impermeable rocks were encountered near $54 \mathrm{~m}$, and the drilling stopped at $62.5 \mathrm{~m}$. A set of bore-hole logs was obtained and a plastic tube with magnetic rings was installed down to a depth of $58 \mathrm{~m}$,

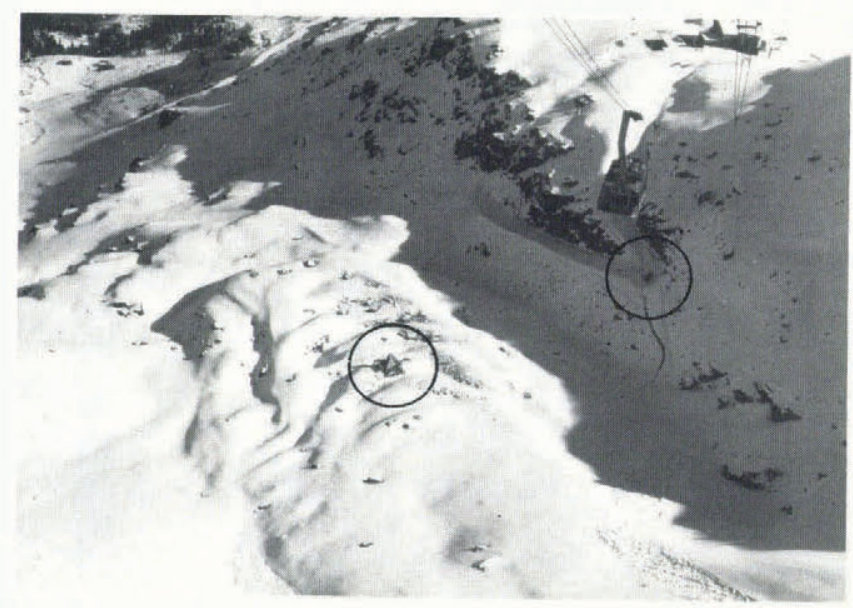

Fig. 1. Active rock glacier Murtel I viewed from the Corvatsch cable car during core drilling. The circles mark the compressor (at the sharp turn of the ski run) and the drilling station in the center of the rock-glacier surface with its ogive-like transverse ridges. 
where loose material had obstructed the bore hole, in order to monitor horizontal as well as vertical bore-hole deformation. Both bore holes remained air-filled (no bore-hole fluid) and were protected with an impermeable lid against atmospheric influences and snow avalanches. Figure 2 illustrates preliminary results of core and bore-hole observations which are helpful in the geothermal analysis presented below (cf. Haeberli and others, 1988, 1989): an upper layer extending from the permafrost table down to $28 \mathrm{~m}$ consists of massive ice and supersaturated sands and silts with an extremely high ice content $(>90 \%$ ice by volume); a lower, saturated layer from 32 to $50 \mathrm{~m}$ mainly contains coarse granodiorite blocks with ice-filled pores; $75 \%\left(4 \mathrm{~cm} \mathrm{year}^{-1}\right)$ of the total horizontal movement at the surface $\left(6 \mathrm{~cm} \mathrm{year}^{-1}\right)$ takes place in super-saturated frozen fine material of the transition zone between these two layers, and the lower (structured) layer does not measurably deform. Vertical compression of about $1 \mathrm{~cm}^{\text {year }}{ }^{-1}$ in a layer immediately above the main shear horizon enables roughly surface-parallel flow to take place in the upper part of the rock-glacier permafrost.

\section{BORE-HOLE TEMPERATURES}

Bore-hole temperatures were measured with two types of negative-temperature-coefficient (NTC) thermistors: Fenwall UUA $41 \mathrm{~J} 1$ with a resistance of approximately $3.27 \times 10^{4} \Omega$ at $0^{\circ} \mathrm{C}$, and Yellow Springs Instrument YSI 44006 with a resistance of about $2.95 \times 10^{4} \Omega$ at $0^{\circ} \mathrm{C}$; both thermistors have a temperature coefficient of about $5 \%$ per ${ }^{\circ} \mathrm{C}$. Thermistors were placed in a metallic cylinder for protection against water and mechanical influences. High-precision calibration of the instruments was done by the Swiss Federal Office of Metrology at Wabern, Bern. The accuracy of thermistor readings in the laboratory is better than $\pm 0.01{ }^{\circ} \mathrm{C}$. Readings under field conditions using a Fluke $8060 \mathrm{~A}$ digital multimeter gave absolute values assumed to be correct within the nearest tenth and relative differences measured with the same thermistor within the nearest hundredth of a degree Centigrade.

A wire equipped with thermistors at intervals of $1 \mathrm{~m}$ was placed in the open bore hole I down to $21 \mathrm{~m}$ depth. In the deep bore hole II, thermistors, again at $1 \mathrm{~m}$ intervals, were mounted on the outside of the plastic tube used for strain measurements, which could be lowered into the bore hole down to $58 \mathrm{~m}$ depth. In the lower part of this hole, from the bottom up to $30 \mathrm{~m}$ below the surface, the space between the plastic tube and the bore hole wall was filled with concrete, whereas in the upper part between $30 \mathrm{~m}$ and the permafrost table water was used, which quickly turned into ice. Within the concrete filling all thermistors developed an instability and were rendered unreliable. The cause is not exactly known, but it may be related to mechanical damage to the cable insulation by a magnetic ring during installation of the plastic tube or to subsequent chemical interaction with the concrete. To obtain temperatures periodically at depths below $30 \mathrm{~m}$, a chain with thermistors at intervals of $2 \mathrm{~m}$ was lowered into the plastic tube down to its bottom. After a few hours of thermal adjustment to the surrounding temperature as checked with thermistors which are firmly installed above $30 \mathrm{~m}$, temperatures were measured and the chain was pulled up $1 \mathrm{~m}$ five times at appropriate time intervals enabling two to three thermistor readings to be taken at every meter. Convection within the air-filled bore holes is assumed to be negligible (cf. Haeberli and Funk, in press). After instrumentation (1 July 1987), measurements were made daily during 1 week. Measurement intervals were extended continuously until August 1987 and readings were taken every 3 weeks thereafter. Temperatures below $30 \mathrm{~m}$ were measured four times a year.

In bore hole I, temperatures were determined between 13 July 1987 and 30 July 1988. During this period, the two bore holes showed similar temperatures. Besides transient effects from drilling disturbance - which lasted less than $6 \mathrm{~d}$ in the case of the open bore hole I as verified by bottom-hole temperature measurements on 14-15 May 1987 - temperature differences between the two bore holes
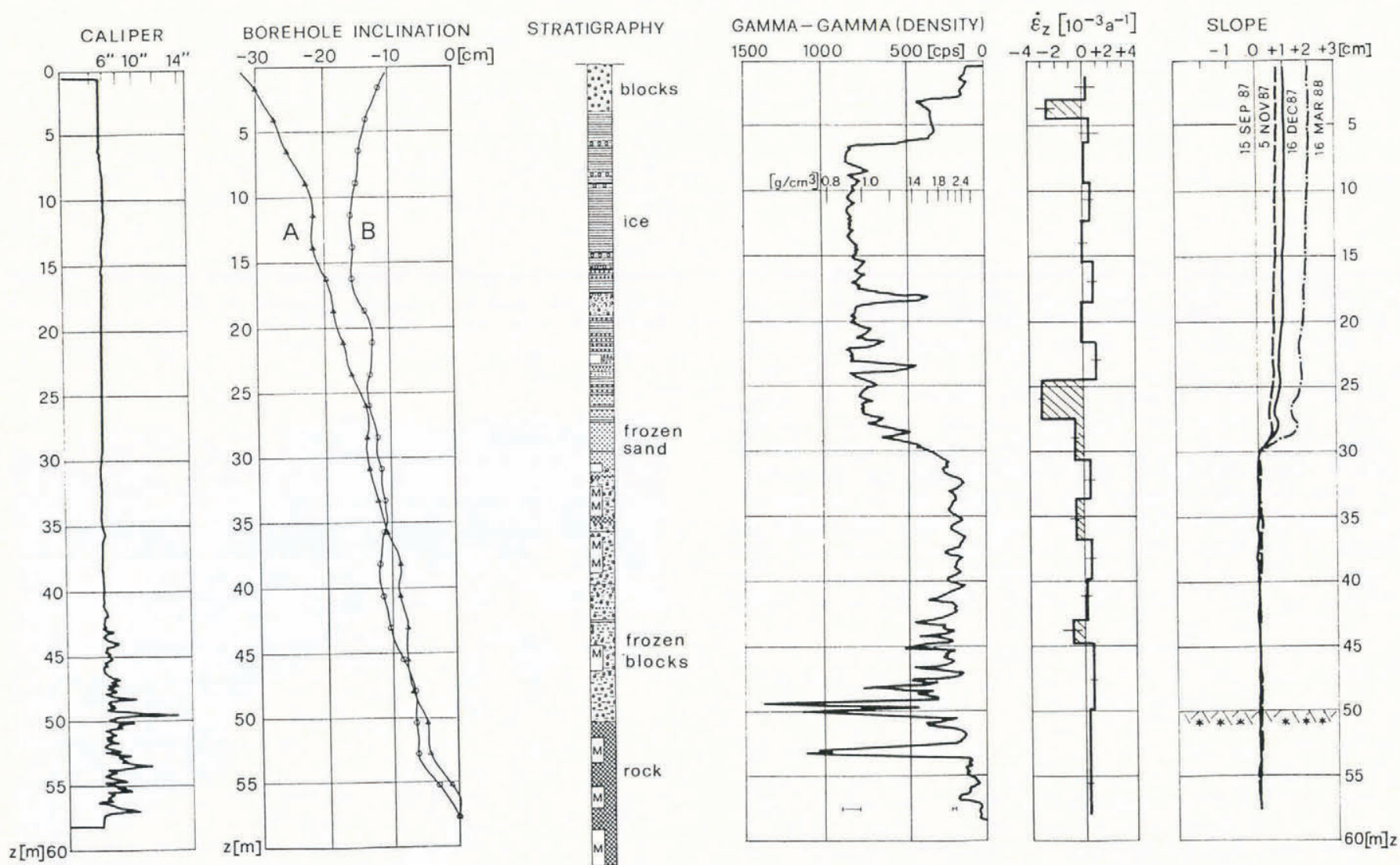

Fig. 2. Bore-hole diameter (caliper) directly after drilling was completed, initial bore-hole inclination (deviation from vertical), core stratigraphy, active $\gamma$-log/density as calibrated by measurements on selected core samples (note irregularities of count rates due to cavity formation below $40 \mathrm{~m}$ depth as indicated in the caliper $\log$ ), vertical $\left(\dot{\varepsilon}_{z}\right)$ and horizontal (slope) bore-hole deformation (cf. text and Haeberli and others (1988, 1989) for explanation). 
were less than $0.1^{\circ} \mathrm{C}$. The following considerations apply to the data from bore hole II. Measurement procedures in the this deep bore hole began $2 \mathrm{~d}$ after completion of the borehole instrumentation. The main thermal disturbance from drilling activity resulted from the infilling of concrete. Comparison with the development of temperatures in the much less disturbed ice-filled section above $30 \mathrm{~m}$ and below the depth of seasonal fluctuations at about $20 \mathrm{~m}$ indicates that the dissipation of warming due to the concrete infilling agrees well with the theoretical concepts proposed by Lachenbruch and Brewer (1959): the thermal disturbance was reduced to a few hundredths of a degree after about half a year (Fig. 3).

Figure 4 illustrates the temperature of the rock glacier as measured during the first year after thermal stabilization. Temperature varies seasonally down to a depth of about $20 \mathrm{~m}$ (= depth of Zero Annual Amplitude, ZAA); it remains negative throughout the year below the permafrost table at about $3 \mathrm{~m}$ and steadily increases with depth from the ZAA down to the permafrost base at $52 \mathrm{~m}$. The following features of the profile deserve special attention:

1. Within the uppermost $15 \mathrm{~m}$, mean annual temperatures are not aligned with the relatively straight temperature profile at greater depth, but curve towards warmer temperatures. Above about $10 \mathrm{~m}$ the temperature gradient is even inverted, probably reflecting a marked but most recent development towards warmer surface tmperatures. "Equilibrium surface temperature" as estimated by extrapolating the linear temperature profile at depth to the surface is around $-3^{\circ} \mathrm{C}$, while mean surface temperature measured in $1987-88$ is close to $-1{ }^{\circ} \mathrm{C}$. Similar thermal of fsets have been described in soil temperature profiles from northern Canada and the U.S.S.R. (Burn and Smith, 1987).

2. Between the ZAA and a depth of $30 \mathrm{~m}$ the temperature gradient is $69 \pm 11^{\circ} \mathrm{C} \mathrm{km}^{-1}$, reducing to $47 \pm 5^{\circ} \mathrm{C} \mathrm{km}^{-1}$ between 30 and $50 \mathrm{~m}$. This break in the temperature profile

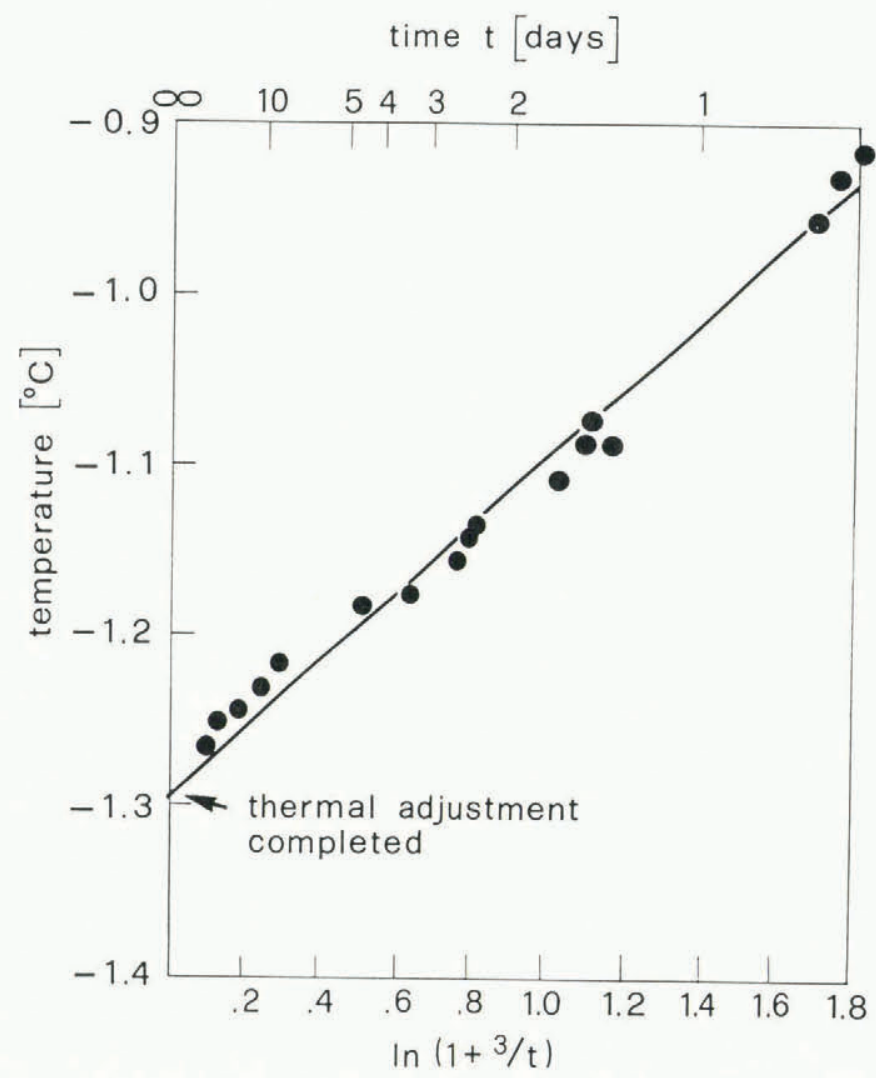

Fig. 3. Dissipation of heat from drilling activity and instrument installation at $27.6 \mathrm{~m}$ depth within the Murtel bore hole. Time $(t)$ is in days after instrument installation (end of thermal disturbance). After thermal adjustment is completed, natural fluctuations of bore-hole temperature take place. The number 3 in the logarithmic time expression corresponds to a $3 d$ warming effect of concrete filling in the bore hole.

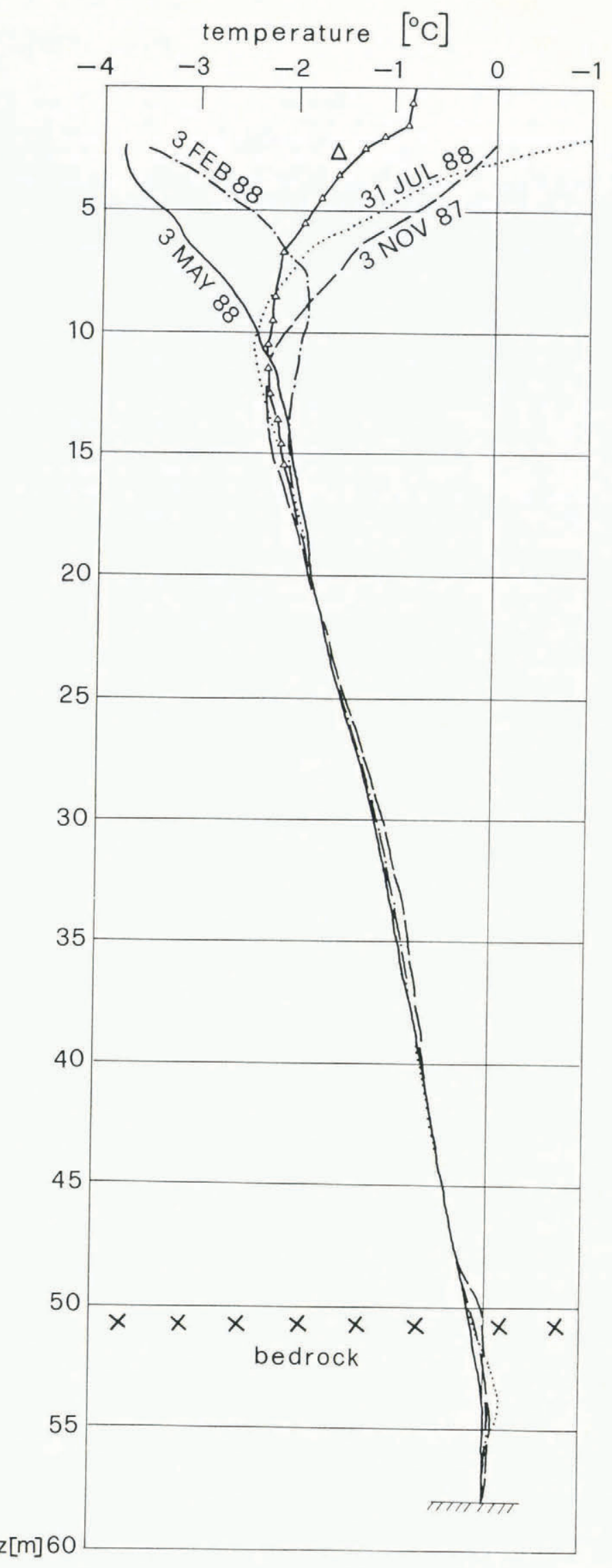

Fig. 4. Seasonal temperature profiles and their mean measured in the bore hole Murtel during the first year after drilling. Note the zone of seasonal variations on the top, thermal adjustment after concrete filling between 25 and $40 \mathrm{~m}$, and seasonal variation below $50 \mathrm{~m}$. Mean temperature $(\Delta)$ above $Z A A$ was calculated by averaging $10 \mathrm{~d}$ readings from interpolated periodical measurements, below $Z A A$ by taking the adjusted temperature ( $c f$. text). 
at around $30 \mathrm{~m}$ depth will be discussed below together with the results from heat-flow calculations.

3. The deepest fragment of ice was detected at $51 \mathrm{~m}$ depth. The temperature measured there is $-0.08^{\circ} \mathrm{C}$, i.e. only about twice the value $\left(-0.035^{\circ} \mathrm{C}\right)$ expected from pressure-induced depression of the freezing point. Hence, no evidence is found in the rock-glacier permafrost for strong chemical or soil-particle effects on freezing-point depression as sometimes observed in polar permafrost (cf. Osterkamp and Payne, 1981; Collet and Bird, 1988).

4. Between 52 and $55 \mathrm{~m}$, i.e. at the permafrost base and within the fissured top zone of bedrock, seasonal fluctuations at slightly positive temperatures can be observed. This phenomenon indeed hints at the possible presence of circulating ground water fed from the surface by seasonal snow and ice melt, possibly also from circulating air.

5. At the bottom of the hole, temperature is again slightly negative $\left(-0.01^{\circ} \mathrm{C}\right)$. This inversion of the temperature gradient between 55 and $58 \mathrm{~m}$ depth remains fairly stable in time, leaving the possibility open that permafrost conditions exist again at greater depth, i.e. beneath the permeable bedrock zone, and that the bore hole penetrates a nonfrozen zone (talik) between 52 and $55 \mathrm{~m}$.

Figure 5 shows measured temperature variations above the ZAA. At the permafrost table - where the mean temperature during the first measurement year was about $-1.3^{\circ} \mathrm{C}-$ high-frequency changes show up and the seasonal temperature variation is strongly asymmetrical. The "zero curtain" due to effects of latent-heat exchange during melting (spring) and freezing (autumn) of the active layer in 1988 has approximately the same duration (cf. Lachenbruch and others, 1962). Because of the insulating effect of the thick snow cover, winter temperatures remain nearly constant at $-4^{\circ} \mathrm{C}$ as expected from earlier snowtemperature measurements for rapid permafrost mapping (cf. King and others, 1987; Hölzle, unpublished), whereas summer temperatures fluctuate more rapidly and with higher amplitudes. At greater depths, high-frequency variations are filtered out, temperature variations become progressively more symmetrical, and below about 9-10 m closely resemble sine curves. Due probably to transient effects from special weather conditions during the first measurement year, however, the period of these sine curves was about 10 months and the temperature minimum in 1988 was slightly warmer than that in 1987, although the latter was still influenced by thermal disturbance from the drilling activity. The seasonal temperature maximum propagating downwards was shifted by about half a year at $10 \mathrm{~m}$ depth with respect to the surface. The amplitude $A$ of the oscillation was attenuated with depth $z$ following the relation

$$
A(z)=A(z=0) \mathrm{e}^{z / m}=4.98 \mathrm{e}^{-0.259 z}
$$

where $m$ represents the slope of the regression line in Figure 5 (correlation coefficient $|r|=0.9978$ ).

\section{THERMAL PROPERTIES}

Thermal conductivity $K$ and thermal diffusivity $k$ are depth: temp:

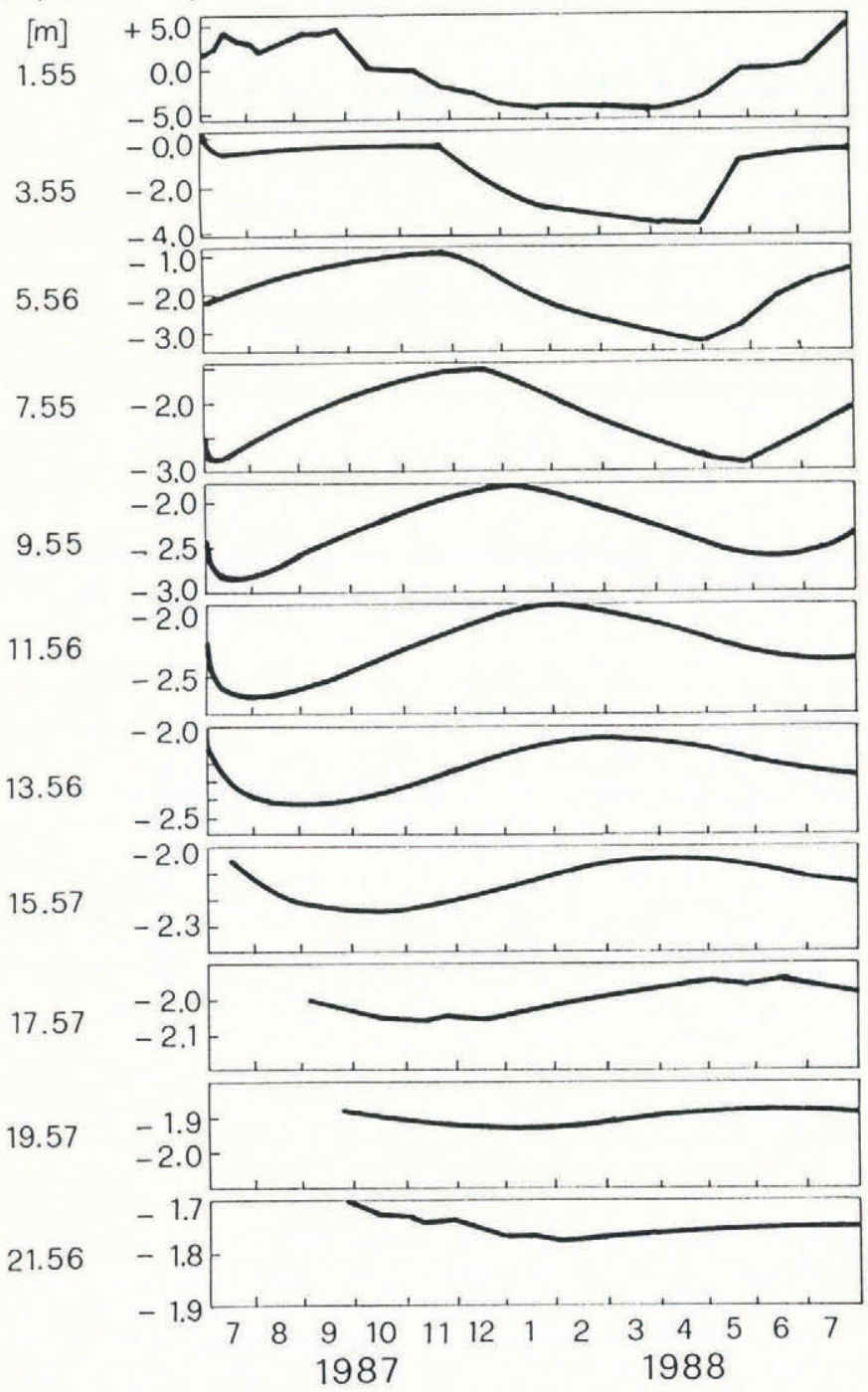

depth:

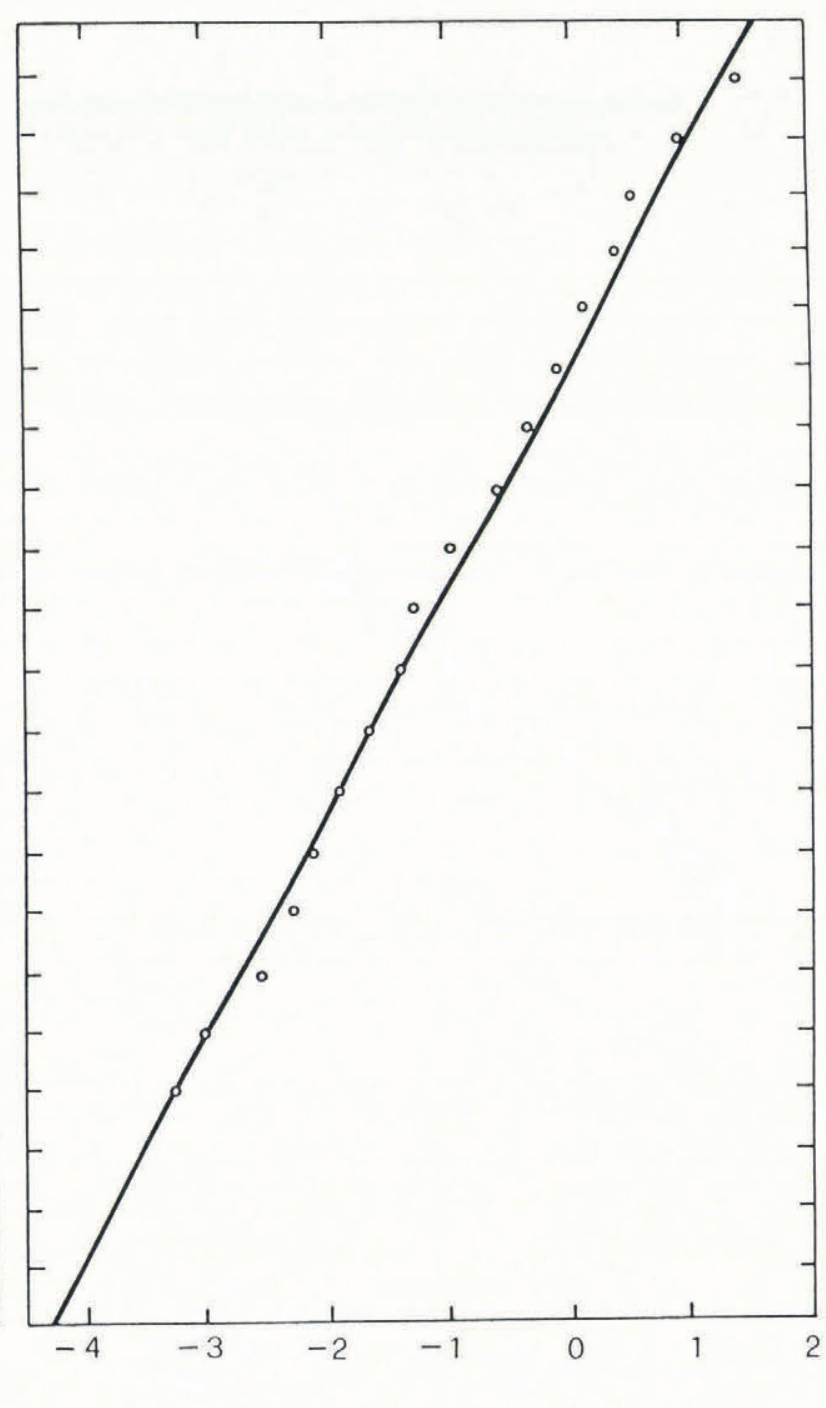

Fig. 5. Seasonal temperature fluctuations above the ZAA as measured at various depths (left) and maximum amplitude $(A(z))$ of annual fluctuation versus depth (right). Note that the temperature scale on the left is variable! 
the two main parameters characterizing the thermal properties of the investigated permafrost. Due to the influence of unfrozen water near the melting temperature and corresponding problems with sample disturbance from core recovery and storage, exact and representative values cannot easily be determined. In order to get realistic estimates for the investigated bore hole, the problem was approached in two ways: by laboratory measurements on frozen material and by theoretical analysis of the seasonal temperature variations observed in the bore hole as described above.

Thermal conductivity $K$ was measured in a cold laboratory using a Quick Thermal conductivity Meter (QTM) composed of a flat-iron-like thermal probe coupled with an electronic processor. The measuring principle is based on a line source on a semi-infinite medium. Only the probe had to be in the cool-room. During measurement, the heater wire's temperature increased by about $10-15^{\circ} \mathrm{C}$. To prevent the sample from reaching the melting point and to avoid corresponding effects from latent-heat exchange, the cold laboratory was set at a temperature of $-18^{\circ} \mathrm{C}$. The thermal conductivity of two rocks (granodiorite and amphibolite) from the rock-glacier surface, an ice sample, and two ice-saturated samples containing silt, sand, and gravel was determined. The ice and ice/rock samples were prepared in the laboratory using ordinary fresh water and fine material collected at the rock-glacier front. The number of randomly oriented measurements on each sample varies between 28 and 54 (Table I).

TABLE I. THERMAL CONDUCTIVITY $K$ OF MATERIAL FROM ROCK GLACIER MURTEL I AS MEASURED WITH A QTM IN THE COLD LABORATORY

$\begin{array}{lcc}\text { Material } & \begin{array}{c}\text { Number of } \\ \text { readings }\end{array} & \begin{array}{c}\text { Thermal conductivity } K \\ \mathrm{~W} \mathrm{~m}^{-1}{ }^{\circ} \mathrm{C}^{-1}\end{array} \\ \text { Granodiorite } & 28 & 2.7 \pm 0.2 \\ \text { Amphibolite } & 30 & 2.3 \pm 0.2 \\ \text { Ice } & 50 & 2.5 \pm 0.2 \\ \text { Two supersaturated } & & \\ \text { ice/debris mixtures } & 54 & 3.0 \pm 0.3\end{array}$

Assuming that the rock glacier's permafrost is composed of about $50 \%$ amphibolite and $50 \%$ granodiorite rocks, the mean thermal conductivity for the rock mixtures in question can be estimated at about $2.5 \mathrm{~W} \mathrm{~m}^{-1}{ }^{\circ} \mathrm{C}^{-1}$, a value which does not significantly differ from the value of ice. Lachenbruch and others (1982) proposed an equation which expresses the thermal conductivity $K$ of an aggregate in terms of the thermal conductivities of its $(n)$ constituents $K_{1}, K_{2}, \ldots, K_{n}$ and their respective volume fractions $\Phi_{1}, \Phi_{2}$, $\ldots, \Phi_{n}$ :

$$
K=K_{1}^{\Phi} \cdot K_{2}^{\Phi_{2}} \cdot \ldots \cdot K_{n}^{\Phi}
$$

Since thermal conductivities of rocks and ice are similar, $K=K_{1}=K_{2}$. However, measured values of thermal conductivity for supersaturated debris mixtures $\left(3.0 \pm 0.3 \mathrm{~W} \mathrm{~m}^{-1}{ }^{\circ} \mathrm{C}^{-1}\right)$ are higher than both, ice as well as rock values. The reason for this discrepancy is not yet clear, but it may be related to increased quartz concentrations in the weathered fine material from the rock-glacier front.

In the absence of sources or sinks of latent heat and of convective heat transport through percolating melt water, temperature $T$ at depth $z$ as a function of time $t$ in a supersaturated permafrost with a presumably low permeability is controlled by heat conduction following the equation (Carslaw and Jaeger, 1959; Tautz, 1971):

$$
\frac{\partial T}{\partial t}=\mathbf{k} \frac{\partial^{2} T}{\partial z^{2}}
$$

$$
T(z, t)=A_{0} \cdot \mathrm{e}^{-z(\omega / 2 \mathrm{k}) \frac{1}{2}} \cdot \sin \left(\omega t-z(\omega / 2 \mathrm{k})^{\frac{1}{2}} .\right.
$$

To calculate thermal diffusivity $k$ from the observed seasonal variations of bore-hole temperatures by analyzing the attenuation of temperature amplitudes and the phase lag of the corresponding sine functions, Fourier series were fitted to three measured temperature-time curves at depths of $6.6,9.6$, and $12.6 \mathrm{~m}$. The following equations were used:

Attenuation of amplitude:

$$
\mathbf{k}=\frac{w h^{2}}{2}\left[\ln \frac{A_{1}}{A_{2}}\right]^{-2} .
$$

Phase lag:

$$
k=h^{2} / 2 \omega \delta^{2}
$$

where $\omega=2 \pi / p, p$ is the period, $h$ represents the vertical separation between the two thermistors corresponding to temperature curves with amplitudes $A_{1}$ (upper) and $A_{2}$ (lower), and $\delta$ means the phase lag between the two sine functions.

For the uppermost $20 \mathrm{~m}$, the thermal diffusivity $k$ can be determined from the slope $m$ of the straight line in Figure 5, assuming that the period $p$ is 1 year:

$$
\mathbf{k}=\pi m^{2} / p
$$

Thermal conductivity $K$, thermal diffusivity $\mathbf{k}$, density $\rho$, and mass specific heat $c$ are related by (Gold and Lachenbruch, 1973):

$$
K=K / \rho c .
$$

Considering that the product $\rho c$ for ice $\left(1.10 \mathrm{~J} \mathrm{~m}^{-3}{ }^{\circ} \mathrm{C}^{-1}\right)$ and granitic rocks $\left(1.30 \mathrm{~J} \mathrm{~m}^{-3}{ }^{\circ} \mathrm{C}^{-1}\right.$; cf. Carslaw and Jaeger, 1959) does not differ much and based on the fact that the ice content is $90-100 \%$ by volume within the considered depth range, thermal conductivity $K$ can be calculated from thermal diffusivity $\mathrm{k}$ :

$$
K\left[\mathrm{~W} \mathrm{~m}^{-1}{ }^{\circ} \mathrm{C}^{-1}\right]=1.93 \times 10^{6}\left[\mathrm{~J} \mathrm{~m}^{-3}{ }^{\circ} \mathrm{C}^{-1}\right] \cdot \mathrm{k}\left[\mathrm{m}^{2} \mathrm{~s}^{-1}\right] .
$$

Table II is a summary of calculated thermal conductivities in $\mathrm{W} \mathrm{m}^{-1}{ }^{\circ} \mathrm{C}^{-1}$ for several layers in a range, where ice content amounts to about $95 \%$ (measured $K$ for pure ice: $2.5 \pm 0.2 \mathrm{~W} \mathrm{~m}^{-1}{ }^{\circ} \mathrm{C}^{-1}$.

TABLE II. THERMAL CONDUCTIVITY $K$ OF LAYERS WITHIN ROCK GLACIER MURTEL I AS CALCULATED FROM SEASONAL TEMPERATURE VARIATIONS
Layer

$0-20 \mathrm{~m}$

$6.6-9.6 \mathrm{~m}$

$9.6-12.6 \mathrm{~m}$

$6.6-12.6 \mathrm{~m}$
$K$

amplitude

$2.9 \pm 0.6$

$1.6 \pm 0.5$

$2.0 \pm 1.1$
$2.5 \pm 0.6$

\section{$K$}

phase lag

$3.0 \pm 0.5$

$1.6 \pm 0.6$

$2.3 \pm 0.8$
The scatter of the calculated values is considerable (roughly $\pm 50 \%$ ). The best agreement with the laboratory measurements is reached with the values for the uppermost $20 \mathrm{~m}$ as a whole and for $6.6-9.6 \mathrm{~m}$ depth. All theoretically calculated values may be influenced by transient effects due to ongoing trends in the development of surface temperatures.

\section{HEAT FLOW}

Besides surface temperature and thermal properties and disregarding the complex processes (phase transitions, convection, etc.) within the non-saturated active layer - a number of factors influence the temperature distribution and heat flow within the creeping permafrost of an active rock 


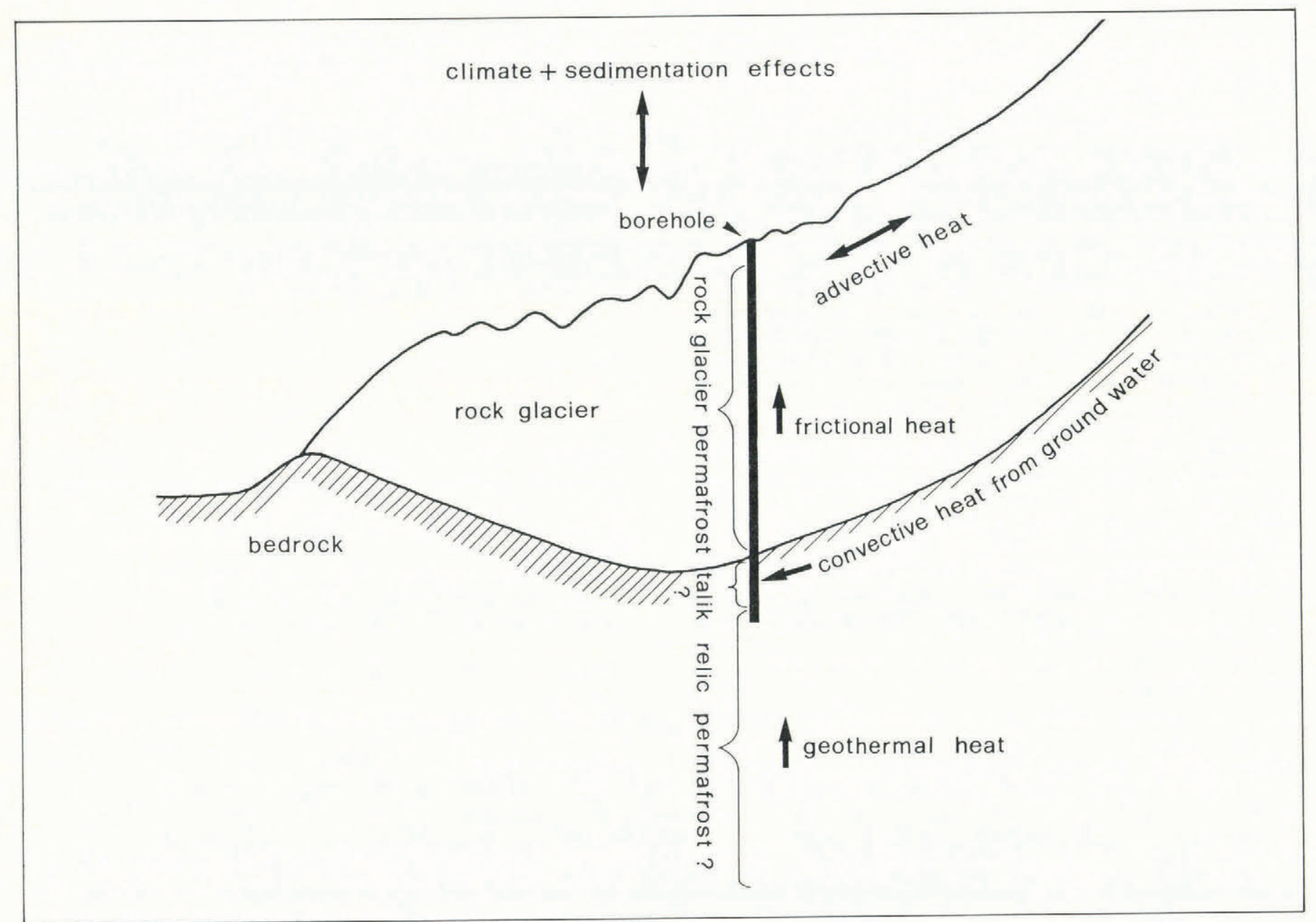

Fig. 6. Scheme of heat sources and heat flow within creeping rock-glacier permafrost.

glacier (Fig. 6): (1) geothermal heat from the underlying bedrock, (2) advective heat from sub-permafrost ground water or air, (3) viscous dissipation from deformation and sliding, (4) advective heat from horizontal displacements and vertical compression, (5) "sedimentation effects" due to the build-up of the rock-glacier body in time (rising surface), and (6) paleoclimatic fluctuations. In addition, threedimensional effects of the extreme surface roughness with its thermal implications (wind-blown crests and snow-filled troughs) could influence the thermal conditions observed in the bore hole. In view of this complexity, the following one-dimensional consideration of heat flow along the bore hole cannot be more than a first attempt to describe the relative importance of some of the processes involved.

Conductive heat flow $q$ along the bore hole is the product of the temperature gradient and the thermal conductivity. Thermal conductivity must be assumed to be constant with depth, since it is identical for ice and encountered rocks within the above-described uncertainties of its determination. Hence, variations in calculated values of $q$ are essentially controlled by variations in the measured temperature gradient. In the zones with annual temperature variations above the $\mathrm{ZAA}$ and beneath the permafrost base, temperature gradients strongly change during the year. In both cases, however, temperature values averaged over the entire observation period indicate negative $q$ values, i.e. heat flow is predominantly towards deeper layers. As mentioned before, these heat-flow inversions point to a most recent warming at the surface and a possible continuation of permafrost beneath the bottom of the hole, i.e. within the underlying bedrock. The latter feature could involve transient effects from secular warming and interference of ground water or air.

The calculated heat flow between the ZAA and the permafrost base at $52 \mathrm{~m}$ varies between about 100 and $220 \mathrm{~mW} \mathrm{~m}^{-2}$ with an overall average of around $150 \mathrm{~mW} \mathrm{~m}^{-2}$. Mean geothermal heat flow in Switzerland is $85 \mathrm{~mW} \mathrm{~m}^{-2}$ with peak values occurring in relation to ascending thermal water (Schinznach Bad and Oberuzwil: $150 \mathrm{~mW} \mathrm{~m}^{-2}$ ) and, hence, being due to convective-flow systems (Bodmer and Rybach, 1985). In comparison, the value observed in the Murtel bore hole is remarkably high. The geothermal map of Switzerland (Bodmer and Rybach, 1984) gives only two measurements for the eastern Grisons, suggesting a regional geothermal heat flow at Murtèl I of about $60-110 \mathrm{~mW} \mathrm{~m}^{-2}$ or one- to two-thirds of the measured average at Murtèl. An important local heat source must therefore exist at the base of the permafrost. The seasonal temperature variations at this depth indeed point to the possible influence of advective heat from relatively rapidly circulating sub-permafrost ground water or air.

At around $30 \mathrm{~m}$ depth, temperature gradient changes quite sharply, indicating an apparent increase in heat flow from a value of $120 \pm 30 \mathrm{~mW} \mathrm{~m}^{-2}$ between 30 and $50 \mathrm{~m}$ to one of $175 \pm 15 \mathrm{~mW} \mathrm{~m}^{-2}$ between $30 \mathrm{~m}$ and the ZAA. Interpretation of this feature involves several possibilities but remains highly uncertain. Undetected variations in thermal conductivity are the most probable reason. However, assuming a simplified two-layer model with pure ice $\left(K=2.5 \mathrm{~W} \mathrm{~m}^{-1}{ }^{\circ} \mathrm{C}^{-1}, \quad q=170 \mathrm{~mW} \mathrm{~m}^{-2}\right)$ on top and $q=$ constant with depth, thermal conductivity of the deeper layer would have to be about $3.6 \mathrm{~W} \mathrm{~m}^{-1}{ }^{\circ} \mathrm{C}^{-1}$. This value is considerably higher than the described laboratory values. It would involve a marked difference between the $K$ values of ice and rocks, respectively, possibly corresponding to a change in rock-quartz content with depth of about $35 \%$. Other explanations may even be less plausible. Viscous dissipation from permafrost deformation within the main shear zone represents a heat source which can be calculated from the shear stress and the measured deformational velocity at the top of the shear zone (Zotikov, 1986) but remains by three orders of magnitude below the required value. The influence of advection from up-stream parts of the creeping permafrost can be estimated using the Peclet number $P$ representing the ratio between characteristic time constants for vertical heat diffusion $\left(T_{1}\right)$ and horizontal heat 
advection ( $T_{2}$, cf. Blatter, 1987); $T_{1}$ is given by $L_{1}^{2} / \mathrm{k}$ and $T_{2}$ by $L_{2} / u$, where $L_{1}$ is the characteristic distance for vertical heat diffusion ( $30 \mathrm{~m}$ in the present case), $k$ is the thermal diffusivity, $L_{2}$ is the characteristic distance for horizontal heat advection, and $u$ is the characteristic horizontal flow velocity $\left(5-10 \mathrm{~cm}_{\text {year }}{ }^{-1}\right.$ in the present case). $P$ is close to 1 if $L_{2}$ is less than a few meters - an order of magnitude which renders strong advective effects rather implausible. Effects of three-dimensional surface topography seem improbable in view of the quite sharp change in $\mathrm{d} T / \mathrm{d} z$, and the same is true for paleoclimatic effects which would have to involve accelerated cooling during the past few years. The observed vertical compression immediately above the main shear zone would also be able to enhance the vertical heat flow in the upper layer, but it takes place at a considerable distance from the main break in $\mathrm{d} T / \mathrm{d} z$. These brief considerations illustrate the relative importance of some processes influencing the heat-flow conditions within an active rock glacier.

\section{DISCUSSION AND CONCLUSIONS}

The most detailed observations reported so far with regard to thermal conditions within creeping mountain permaf rost are those by Johnson and Nickling (1979) from a partially vegetation-covered active rock glacier near Kluane Lake, Yukon Territory, Canada, and the shallow-depth measurements by Haeberli (1985) from the active Gruben rock glacier in the Swiss Alps. The bore-hole measurements down to $17 \mathrm{~m}$ depth near Kluane Lake indicated rapid warming and degradation of permafrost, coupled with thermokarstic development, whereas the average surface temperature at Gruben remained close to $-1{ }^{\circ} \mathrm{C}$ over several years. Drilling through the active rock glacier Murtèl I now promotes a more complete discussion of temperature, thickness, and stability of rock-glacier permafrost.

Average temperature for recent years at the permafrost table of the rock glacier is estimated at about $-3^{\circ} \mathrm{C}$. Considering the fact that the twentieth century is among the warmest periods within post-glacial time, permafrost conditions have probably existed during the whole of the Holocene and, hence, during the entire time of rock-glacier formation in the Alps (cf. more detailed discussion by Haeberli (1985)).

The thermally defined base of the permafrost at $52 \mathrm{~m}$ depth is very close to the base of the ice-rich permafrost as given by the debris/bedrock interface near $50 \mathrm{~m}$ depth. It can easily be estimated in this case (cf. Osterkamp, 1984; Haeberli, 1985) that melting at the permafrost base as a consequence of surface temperature suddenly rising to $0{ }^{\circ} \mathrm{C}$ would take place after about a decade only. Complete melting of the permafrost by geothermal heat alone would then take several thousand years. With surface temperatures rising even further, i.e. above $0^{\circ} \mathrm{C}$, melting from the surface downwards could be faster, but permafrost degradation would even then take many decades if not centuries to be completed. These orders of magnitude clearly show that rock-glacier permafrost has a long "memory" and that its thermal state must be explained with due consideration to past developments.

In a number of Arctic permafrost bore holes, thermal anomalies have developed as a consequence of recent temperature changes, with reduced or even inverted heat flow above about $150 \mathrm{~m}$ depth due to warming in the early twentieth century and with normal to increased heat flow within the uppermost $50 \mathrm{~m}$ due to cooling since around 1950 (Lachenbruch and others, 1988). Permafrost in the Alps is thought to have warmed up as well following the end of the Little Ice Age around 1850; its thickness and temperature profile may therefore not be in equilibrium with present-day conditions at the surface (Haeberli, 1985). Permafrost thickness at Murtèl I could easily have been $100 \mathrm{~m}$ or more during the Little Ice Age, if one assumes average geothermal heat flow, no thermal influence from ground water, and a mean surface temperature colder than today by about $1^{\circ} \mathrm{C}$. The possibility that relict permafrost from the Little Ice Age indeed still exists below the depth reached by the bore hole - as indicated by the inversion of the heat flow near the bottom of the hole - is therefore not unreasonable. Slight cooling of surface temperatures during the past decades may have increased the heat flow above $50 \mathrm{~m}$ depth. At some time in the past, ground water or air circulating within the heavily fissured top layer of the bedrock may have started to form a talik with a sharp break in the temperature profile and, hence, to increase even further the heat flow in the permafrost above (cf. Echelmeyer, 1987). Long-term monitoring of bore-hole temperatures is continuing to permit timedependent modelling of such scenarios and documentation of future trends.

With regard to the fact that the front of rock glacier Murtèl I is advancing over permafrost-free terrain, the mean annual surface temperature of about $-3^{\circ} \mathrm{C}$ at the drill site, about $200 \mathrm{~m}$ behind the front, is remarkably low. Moreover, it is very close to the mean annual air temperature as calculated from weather stations, despite the thick winter snow cover usually existing at this site. Rock-glacier permafrost obviously reflects an especially cold micro-climatic environment and extreme gradients of surface-temperature conditions must exist at the rock-glacier front. As neither air temperature nor incoming solar radiation changes dramatically between the drill site and the terrain in front of the rock glacier, surface characteristics must be assumed to play an important role. The prevailing absence of systematic studies about active-layer processes on rock glaciers, however, renders all explanations speculative. It is possible that the permafrost of rock glaciers creates its own micro-climate by various processes such as heat loss through water run-off and, hence, that critical threshold values could exist with regard to its stability. Such important aspects remain to be investigated.

\section{ACKNOWLEDGEMENTS}

The study was funded by a special grant from ETH Zürich (permafrost core drilling, project 0230.70). The help of P. Gnos (VAW) and a number of colleagues during the preparation and installation of the thermistors is gratefully acknowledged. Thanks are also due to Professor S. Müller and Professor L. Rybach from the Geophysical Institute of ETH Zürich, as well as to $\operatorname{Dr} A$. Iken and Dr M. Funk (VAW) for critical comments on the manuscript and helpful suggestions. B. Nedela assisted with the drawings and S. Braun edited the English of the present paper.

\section{REFERENCES}

Barsch, D. 1973. Refraktionsseismische Bestimmung der Obergrenze des gefrorenen Schuttkörpers in verschiedenen Blockgletschern Graubündens, Schweizer Alpen. $Z$. Gletscherkd. Glazialgeol., 9(1-2), 143-167.

Barsch, D. 1977. Ein Permafrostprofil aus Graubünden, Schweizer Alpen. Z. Geomorphol., 21, 79-86.

Barsch, D. 1978. Arctic rock glaciers as indicators of discontinuous Alpine permafrost. An example from the Swiss Alps. In Third International Conference on Permafrost, ... 1978, Edmonton, ... Proceedings. Vol. 1. Ottawa, National Research Council of Canada, 349-353.

Barsch, D. and G. Hell. 1976. Photogrammetrische Bewegungsmessungen am Blockgletscher Murtèl I, Oberengadin, Schweizer Alpen. Z. Gletscherkd. Glazialgeol., 11(2), 1975, 111-142.

Blatter, H. 1987. On the thermal regime of an Arctic valley glacier: a study of White Glacier, Axel Heiberg Island, N.W.T., Canada. J. Glaciol., 33(114), 200-211.

Bodmer, P. and L. Rybach. 1984. Geothermal map of Switzerland (heat flow density). Matér. Géol. Suisse. Géophys. 22.

Bodmer, P. and L. Rybach. 1985. Heat flow maps and deep ground water circulation: examples from Switzerland. $J$. Geodyn., 4, 223-245.

Burn, C.R. and C.A.S. Smith. 1988. Observations of the "thermal offset" in near-surface mean annual ground temperatures at several sites near Mayo, Yukon Territory, Canada. Arctic, 41(2), 99-104.

Carslaw, H.S. and J.C. Jaeger. 1959. Conduction of heat in solids. Second edition. Oxford, Clarendon Press.

Collett, T.S. and K.J. Bird. 1988. Freezing-point depression at the base of ice-bearing permafrost on the northern 
slope of Alaska. In Senneset, K., ed. Permafrost. Fifth International Conference, August 2-5, 1988. Proceedings. Vol. 1. Trondheim, Tapir Publishers, 50-55.

Echelmeyer, K. 1987. Anomalous heat flow and temperatures associated with subglacial water flow. International Association of Hydrological Sciences Publication 170 (Symposium at Vancouver 1989 - The Physical Basis of Ice Sheet Modelling), 93-104.

Giardino, J.R. and J.D. Vitek. 1988. Rock glacier rheology: a preliminary assessment. In Senneset, K., ed. Permafrost. Fifth International Conference, August 2-5, 1988. Proceedings. Vol. 1 . Trondheim, Tapir Publishers, $744-748$

Gold, L.W. and A.H. Lachenbruch. 1973. Thermal conditions in permafrost - a review of North American literature. In North American Contribution. Permafrost. Second International Conference, 13-28 July 1973, Yakutsk, U.S.S.R. Washington, DC, National Academy of Sciences, 3-25.

Haeberli, W. 1985. Creep of mountain permafrost: internal structure and flow of Alpine rock glaciers. Eidg. Tech. Hochschule, Zürich. Versuchsanst. Wasserbau, Hydrol. Glaziol. Mitt. 77.

Haeberli, W. and M. Funk. In press. Bore-hole temperatures at the Colle Gnifetti core drilling site (Monte Rosa, Swiss Alps). J. Glaciol.

Haeberli, W., J. Huder, H.-R. Keusen, J. Pika, and H. Röthlisberger. 1988. Core drilling through rock glacier-permafrost. In Senneset, K., ed. Permafrost. Fifth International Conference, August 2-5, 1988. Proceedings. Vol. 2. Trondheim, Tapir Publishers, 937-942.

Haeberli, W., M. Gamper, M. Zimmermann, and H Kienholz. 1989. Morphogenesis and morphodynamics in high mountain environments. Field Trip D4 Swiss Alps, Second International Conference on Geomorphology. Geoökoforum 1, 264-298.

Hölzle, M. Unpublished. Untersuchungen zur Permafrostverbreitung im Oberengadin. (Diploma thesis, Eidgenössische Technische Hochschule, Zürich, 1989.)

Johnson, J.P. and W.G. Nickling. 1979. Englacial temperature and deformation of a rock glacier in the Kluane Range, Yukon Territory, Canada. Can. J. Earth Sci., 16(12), 2275-2283.

King, L., W. Fisch, W. Haeberli, and H.P. Waechter. 1987. Comparison of resistivity and radio-echo soundings on rock glacier permafrost. Z. Gletscherkd. Glazialgeol., 23(1), 77-97.

Lachenbruch, A.H. and M.C. Brewer. 1959. Dissipation of the temperature effect of drilling a well in Arctic Alaska. U.S. Geol. Surv. Bull. 1083-C, 73-109.

Lachenbruch, A.H., M.C. Brewer, G.W. Greene, and B.V. Marshall. 1962. Temperatures in permafrost. In Temperature - its measurement and control in science and industry. Vol. 3, Part 1. New York, Reinhold Publishing Corp., 791-803.

Lachenbruch, A.H., J.H. Sass, B.V. Marshall, and T.H. Moses, jr. 1982. Permafrost, heat flow, and the geothermal regime at Prudhoe Bay, Alaska. J. Geophys. Res., 87(B11), 9301-9316.

Lachenbruch, A.H., T.T. Cladouhos, and R.W. Saltus. 1988. Permafrost temperature and the changing climate. In Senneset, K., ed. Permafrost. Fifth International Conference, August 2-5, 1988. Proceedings. Vol. 3. Trondheim, Tapir Publishers, 9-17.

Lange, G.R. 1973. Investigation of sampling perennially frozen alluvial gravel by core driling. In North American Contribution. Permafrost. Second International Conference. 13-28 July 1973, Yakutsk, U.S.S.R. Washington, DC, National Academy of Sciences, 535-541.

Osterkamp, T.E. 1984. Response of Alaskan permafrost to climate. In Permafrost. Fourth International Conference, July 17-22, 1983. Final proceedings. Washington, DC, National Academy Press, 145-152.

Osterkamp, T.E. and M.W. Payne. 1981. Estimates of permafrost thickness from well logs in northern Alaska. Cold Reg. Sci. Technol., 5(1), 13-27.

Smith, M.W. 1988. The significance of climatic change for the permafrost environment. In Senneset, K., ed. Permafrost. Fifth International Conference, August 2-5, 1988. Proceedings. Vol. 3. Trondheim, Tapir Publishers, 18-23.

Tautz, H. 1971. Wärmeleitung und Temperaturausgleich. Berlin, Akademie-Verlag.

Vonder Mühll, D. Unpublished. Geothermische Studien zur Permafrost-Bohrung Murtèl-Corvatsch. (Diploma thesis, Eidgenössische Technische Hochschule, Zürich, 1988.)

Wahrhaftig, C. and A. Cox. 1959. Rock glaciers in the Alaska Range. Bull. Geol. Soc. Am., 70(4), 383-436.

Zotikov, I.A. 1986. The thermophysics of glaciers. Dordrecht, etc., D. Reidel Publishing Co. 